\title{
sciendo
}

DOI: $10.2478 /$ abcsj-2019-0021

American, British and Canadian Studies, Volume 33, December 2019

\section{Political Theatre in the Age of Brexit: The State of Nation in Monologues}

\author{
BANU ÖĞÜNÇ \\ Aksaray University, Aksaray, Turkey
}

\begin{abstract}
On the British stage, political theatre, which emerged in the twentieth century, has been linked with the problems of the working class as initiated in the 1920s until the early 1960s. With the end of the official censorship of theatre in 1968, political theatre in Britain experienced a period in which socialist works marked the stage. Nevertheless, the 1990s challenged the association of political theatre with the conditions of the working class. Considering the current political and social events in Britain and around the world, it is appropriate to underline that political theatre is not only in a constant flux, but its definition has been once again challenged. In this regard, Brexit can be considered as one of the most significant movements to influence the understanding of political theatre in the twenty-first century. Consequently, this study aims to analyse Brexit Shorts: Dramas from a Divided Nation (2017), a co-production by the Guardian and Headlong Theatre Company and discuss their contribution to the changing definition of political theatre. Brexit Shorts will be further explored regarding their influence on the popularity of monologues as a mode of performance.
\end{abstract}

Keywords: political theatre, Brexit, monologue, digital theatre, online drama

\section{Tracing Back the Definition of Political Theatre}

Amelia Howe Kritzer argues that "[i]n a sense, all theatre is political" (1); however, a specific definition of political theatre has been established in line with the historical background of the term from agitprop theatre by Erwin Piscator and Bertolt Brecht. Influenced by Piscator, Michael Patterson suggests the following definition of political theatre: "This is 
defined as a kind of theatre that not only depicts social interaction and political events but implies the possibility of radical change on socialist lines: the removal of injustice and autocracy and their replacement by the fairer distribution of wealth and more democratic systems" (3-4). Political theatre marked the British stage beginning with the 1970s with names such as John McGrath, David Hare, Howard Brenton, Cary Churchill and Howard Barker. As a common characteristic, political theatre in Britain represented leftist ideology influenced by Brecht's epic theatre. This definition of political theatre refers to Graham Holderness' comment as well: "Books about political theatre, essays on political drama, concern themselves wholly with left wing production, largely with socialist, Communist and revolutionary Marxist work" (4).

Nevertheless, critics began to question the definition of political theatre especially after the change of mood in Britain following Margaret Thatcher's premiership. Kritzer observes the influence of this change on political theatre as follows: "By the early 1990s, the energy of opposition had dissipated, and political theatre, no less than political parties of the left, had failed to articulate ideas that expressed the aspirations of the majority of the public" (6). It can be argued that certain political developments in Britain in the post-Thatcher era have influenced political theatre as well. Besides the influence of Thatcherism, the rise of New Labour has also had an impact on political theatre in the UK. Moreover, a new definition and approach needed to be established in line with these political and social changes. In order to provide this, Maggie B. Gale and John F. Deeney refer to what Michael Kirby suggested in the 1970s in order to introduce a revised definition for political theatre:

Writing in the mid-1970s, Michael Kirby made the distinction between political theatre which engages in issues of government or party politics, and that which aims simply to 'change the beliefs and opinions of the spectator' (Kirby 1975: 132). He also notes however that some political theatres do 'not proselytise', are 'not didactic' and 'do not support particular alternatives' (ibid: 135). This broad framework for the definition of political theatre is one we adopt here. (291)

The framework suggested by Kirby has begun to be adopted by the critics who study political theatre in the post-Thatcher era. Eventually, the 
understanding of political theatre as taking a leftist stand to defend its ideology, and delivered through Brechtian techniques, started to broaden in the 1990s. Gale and Deeney, for instance, add pluralism to the definition of political theatre:

The term 'political theatre' is a contentious one which is in part why this section names political theatres in the plural. During the 1980s and 1990s, scholarship differentiated between political theatres influenced by Brecht theatres of the political left - and other theatres which were political in content and perhaps explored political issues, but did not challenge or develop traditional or dominant theatrical forms. (291)

The emergence of in-yer-face theatre in the 1990s stands for a significant proof of the changes in the understanding of political theatre. Consequently, both the political developments and the changes on the British stage have altered political theatre and paved the way for a plural understanding of political theatre.

Such developments have inevitably raised the question of the necessity to redefine political theatre in the post-Thatcher era. Kritzer suggests the following definition:

[T] heatre is considered political if it presents or constructs a political issue or comments on what is already perceived as a political issue. Defined in this way, political theatre initiates a dialogue with the audience about politics within a national or cultural system shared by both the creators of the theatre production and the audience. (10)

Rather than defending an ideology, political theatre of the post-Thatcher era aims to establish a dialogue and mutual understanding of the political problems of the age. This can be observed in the political plays of the 1990s, and later 2000s, which represent different racial and social backgrounds and deal with political and social issues such as race.

Nevertheless, the rise of Jeremy Corbyn as the leader of the Labour Party has altered not only the Labour Party, but also political ideologies in general. Hence, these contemporary developments have led to a revised definition of politics and political theatre. Similar to the distinction that Kritzer makes for the post-Thatcher era, a post-Brexit era may be 
considered in light of the political stances and ideologies that it generates for political theatre to continue to be functional.

\section{Search for a New Technique on the Stage}

Due to the significant change in the political climate from the 1970s onwards, contemporary playwrights have begun to distance themselves from Brechtian techniques. More precisely, they use different techniques and methods in order to express their ideas and criticism, as can be observed in in-yer-face and later in Hans-Thies Lehmann's definition of postdramatic theatre. In this regard, the popularity of verbatim theatre has started to increase on the British stage, thus re-defining political theatre in the new millennium. According to Mary Luckhurst, the term has its roots in Latin and means that "the moment of utterance is privileged, and 'verbatim theatre.' in its purest sense, is understood as a theatre whose practitioners, if called to account, could provide interviewed sources for its dialogue, in the manner that a journalist must, according to the code of ethics, have sources for a story" (201). While the term was coined by Derek Paget, the heritage of verbatim theatre can be traced back to the propagandist theatre of the 1920s and 1930s. As political theatre has been understood and redefined throughout the decades to reflect certain social and political changes, the significance of verbatim theatre has also changed. The terrorist attacks in New York and London, for example, have led to a post $9 / 11$ era. According to Sarah Beck, "[i]n the early $21^{\text {st }}$ century Great Britain witnessed a resurgence of verbatim plays reflecting on the effects of trauma and social suffering" (21). The distrust and suspicion that have dominated the Western societies in the post 9/11 era have also generated a reconfiguration of verbatim theatre in political theatre, as David Edgar indicates: "The war on terror brought politics back on the world stage, and it's no surprise that politics returned to theatrical stages as well. But the predominance and resilience of verbatim, witness and testimony theatre needs explaining" ("Doc and Dram").

Richard Norton-Taylor's and Nicholas Kent's production The Colour of Justice (1999) shows the growing importance of testimonies. The play was written in response to the Stephen Lawrence case by the 
investigative journalist Norton-Taylor on the basis of the transcripts of the inquiry and some other official documents on the case. The Colour of Justice had its premiere at the Tricycle Theatre and moved to West End's Victoria Palace Theatre as a result of public attention, which indicates the significance and power of verbatim theatre. Michael Billington describes the public's response to the play as follows: "It is fascinating to note that in 1999 when The Tricycle Theatre staged its edited version of the Stephen Lawrence enquiry, the event commanded a large amount of space: precisely because the theatre was engaging directly with a topical, public event" ("The State" 55). Hence, as Luckhurst points out, The Colour of Justice has paved the way for verbatim theatre to be popularized on the stage (209). With respect to this, Out of Joint Theatre Company represents an important place for verbatim theatre and makes a significant contribution to the development of political theatre through the plays they staged by David Hare and Robin Soans especially. Thus, it can be argued that the evolving definition of political theatre has been shaped once again in a new political atmosphere with verbatim theatre. Nevertheless, verbatim theatre can be re-evaluated in line with the evolving definition of political theatre. In this regard, recent academic studies look into how the digital age has contributed to verbatim theatre, and, in this sense, the analyses of the Guardian's project are particularly helpful in reinterpreting it.

\section{Change of Subject: Brexit}

Political theatre, through the decades, has been redefined by the new playwrights, as a result of certain political and social changes in the society. As Patterson argues, political theatre at the beginning of the new millennium will dominate the stage as it did in the 1970s: "It remains unclear when and how political theatre may re-emerge. That it will, given the continuing injustices of the world, I regard as inevitable. That, when it does, it will draw on the work of a group of remarkable British playwrights of the last century, I regard as highly desirable" (179). If nothing else, Brexit, the term used to refer to the decision of the majority in the UK to leave the European Union, may offer the new generation of 
playwrights the opportunity to transpose these political developments to the British stage and, thus, to contribute to further conceptions of political theatre. As a result of extensive debates on the relationship of the UK with the European Union, when the Conservative Party won the 2015 general election in the UK, David Cameron felt obliged to go for a referendum on the decision whether to remain in or leave the European Union. Discussions on the referendum which can be traced back to 2012, finalized on 23 June 2016. 52\% of the British people voted to leave the European Union. Hence, under the leadership of Theresa May, the United Kingdom began negotiations on 29 March 2017 to leave the European Union. Since then, Brexit continues to make the headlines as May could not finalise the process, which has created new discussions along with new questions in the UK and the EU. While Brexit is mainly a political event, the UK's exit from the European Union is too complex to be discussed merely as a political issue. Since the referendum, Brexit has been the most contentious topic for politicians, academics and ordinary citizens to be understood, analysed and discussed from the perspectives of politics, economy, trade and even daily life. Beyond all these matters, I aim to initiate a discussion of the following questions: What does Brexit mean for political theatre in Britain in the $21^{\text {st }}$ century? Can we expect Brexit to trigger political theatre to gain popularity on the British stage as Patterson refers to? Or, more appropriately, can we consider Brexit as another landmark, similar to the classification as post-Thatcher era, in history initiating certain changes and developments on the stage as well?

The first reaction to Brexit on the British stage came from Britain's Poet Laureate Carol Ann Duffy through her play My Country, a work in progress for which she has collaborated with the National Theatre's artistic director Rufus Norris. As stated on the National Theatre's website, "[i]n the days following the Brexit vote, a team from the National Theatre of Great Britain spoke to people nationwide, aged 9 to 97, to hear their views" ("My Country"). The real speeches of the party leaders were interwoven with these testimonies creating the bases of the play's script. According to Paul Taylor, the play "could be described as a verbatim post-Brexit Cantata" ("My Country"), and he further praises Duffy's poetical skill. Hence, My Country follows in the tradition of verbatim 
theatre and represents an example of political theatre as well. Billington, on the other hand, criticizes the play as political theatre: "however wellintentioned, the show offers little in the way of fresh information or insights. ... Even though the show ends with a plea for 'good leadership', it offers no hint from where, in our disunited kingdom, that might conceivably come" ("My Country"). David Upton concludes his analysis in a similar vein: "Theirs are the diverse voices that have become disconnected, often from one another, in a debate where there was a lot of talking and not a lot of listening. The sense of frustration is palpable and alarming, prompting Britannia's final plea 'for good leadership' to be delivered direct to the audience"' ("My Country"). Susannah Clapp also expresses her dissatisfaction as follows: "We are in a different, more obviously dark condition, the closest to civil war than any time in my life. Old friends cannot bear to be in the same room with those who voted differently. That is the country I would like to see on stage now. This looks like a soft dodging of a painful conflict" ("My Country"). Regardless of the criticism of the play, Duffy's play deserves recognition for its contribution to political and verbatim theatre through its lyricism, mentioned by a great number of reviews. Moreover, the play can be considered a significant step in generating further interest in plays that tackle Brexit, as Dom O'Hanlon points out: “Greater plays about the issue, the debate and the fallout will no doubt arrive but this is a powerful and affecting portrayal of Britain in the moment and as a 'work in progress', effectively presented and lyrically told" ("Review of").

\section{A Responsibility Project: The Guardian's Brexit Shorts}

Following Duffy's play, the Guardian initiated a project to offer leading playwrights the opportunity to write about Brexit. As Chris Wiegand explains, "[n]ine leading playwrights from around the UK have written a major new series of online dramas responding to the causes and consequences of the EU referendum result" ("Brexit Shorts"). Brexit Shorts: Dramas from a Divided Nation, a co-production by the Guardian and Headlong Theatre Company, includes monologues written by distinguished playwrights such as: Abi Morgan, Meera Syal, Maxine 
Peake, David Hare, Gary Owen, Charlene James, AL Kennedy and Stacey Gregg. Among these names, English playwright, screenwriter, film and theatre director David Hare is a well-known name due to his involvement in political theatre. His monologue is entitled "Time to Leave" in which a woman in her fifties, named Eleanor, shares her confused feelings after she has voted to leave. Although the monologue is not very extensive, Hare creates a complex character who challenges the audience to reflect on the political condition of the country beyond a simple political decision of whether to leave or remain in the EU. In this regard, Hare also raises the question of national identity and what it really means to be British and/or English, Scottish, Welsh, Irish.

The monologue which begins as if supporting the decision to leave the EU, in fact, ends in a complicated stance in terms of its political tone. While Hare's character replies to the comment on losing Scotland as "I say you can't lose what you never had," the Guardian's project includes a Scottish writer, A. L. Kennedy, who contributes with the monologue entitled "Permanent Sunshine" whose narrator is a young man described as "too poor to be clever, wild, sharp, thin, fast." In his monologue, Kennedy's character, Chummy, employs a Scottish accent emphasising the character's Scottish background. Chummy, in his direct address to the camera, sounds as if he were engaged in a dialogue with an imaginary interlocutor to whom he refers as 'you' while frequently referring to himself as 'we.' Hence, in a similar way to the two sides in the referendum, Kennedy creates a divided position as 'we' and 'you.' Not only may the explanation for the narrator's choice of pronouns be interpreted in relation to those who voted to leave and those who voted to remain, but it may also show an internal division between the nations, specifically the English versus the Scots. Instead of defending a vote, Kennedy's character, Chummy, makes a statement regarding the identity problem when he refers to the division between the Scottish and the English identities and the possibility of a referendum on the decision to leave the UK, which might come into discussion again in Scotland after Brexit.

As a Belfast-born Irish playwright, Stacey Gregg touches upon the issue from the perspective of Northern Ireland. In the monologue, entitled 
"Your Ma's is a Hard Brexit," the main character, a Protestant workingclass mother, evaluates the vote from the perspective of Ireland as she walks by the peace-line. She also acknowledges the need for constructive dialogue between the two opposing groups: "Like, we know what it means to be divided. We're not too bad at that ourselves!" ("Your Ma's"). Furthermore, she approaches Brexit from a wider perspective reflecting on long-term political problems in Ireland. The play ends as the camera focuses on the narrator's child, who represents the future. Hence, the ending may stand for a subtle warning of the audience about the major concern that should be a guide for political decisions.

The project also includes a monologue by the British-Indian playwright, comedian, writer, producer and actress Meera Syal. In Syal's "Just a T-Shirt," Priti, a middle-aged British-Indian woman is under interrogation because of a violent racial incident when she and her Polish neighbour fall victims to a street attack by a man whose T-shirt reads 'WE WON! NOW SEND THEM ALL BACK!'. Priti represents the minorities' perspective regarding the referendum. When asked about how she voted in the referendum, Priti expresses her concerns with regard to the threat that immigrants may pose for job security. After this point, the monologue gets even more complicated when discussions revolve around the issues of the status of British citizens versus that of immigrants. When race is in question, once again, the political discussion in the monologue deviates from the referendum and focuses on the colonial history of the country. In this regard, Syal's play shows similarities with the ones written by Gregg and Kennedy, who also carry the conditions of different ethnic and social groups in the UK beyond the specific political decision of Brexit.

In contrast to Syal's character, English actress Maxine Peake's monologue "Shattered" gives voice to an immigrant lawyer, Dalir, from Manchester. As a lawyer, he narrates his own experiences with different immigrants, underlying the influence of Brexit on immigration. On the one hand, he complains about the chaos Brexit has created regarding the legal status of immigrants and EU citizens; on the other hand, he is quite enthusiastic to fight legally to defend immigrants' and other EU citizens' rights. As he explains, "[w]e had no funding, no premises, but we had the backing of people who shared our view, that free legal advice is a human 
right! Moss Side has embraced us" ("Shattered"). Thus, according to Dalir, this political uncertainty has also led to better unity between those in need of legal and social assistance. Rather than an outcome of a political decision, the reaction and the process become more significant. Peake's monologue celebrates the human values of unity and solidarity in the face of the decision to break away from the EU.

"The Pines" by Welsh playwright Gary Owen is another monologue in the Guardian project. The protagonist is a Welsh dairy farmer, who is angry and tired because he cannot earn enough to sustain a decent living on the farm. The monologue conveys the feelings of the farmer as he has been left out in the changing conditions of the country. He can neither survive on his job nor find any other opportunity to improve his situation. The final scene shows the encounter between the owner of the café and the farmer: "She was staring at her iPad saying - it just doesn't feel like my country any more. And I couldn't help but think - now you know how we feel" ("The Pines"). The farmer's observation indicates how hopeless he feels and his expectations of the referendum to make a difference, at least with respect to raising awareness of economic problems among people. At the same time, he draws attention to the position of Wales as alienated from Britain.

Furthermore, and unlike the angry and confused characters examined above, James Graham's "Burn" proposes a highly entertaining monologue with Carol, a Mansfield mother and internet troll, as the main character. Sitting at her desk, and surrounded by drinks and chips, Carol constantly shifts from her android phone to the desktop while talking to the camera in between this movement. She may be viewed as an Internet troll because she pits remainers against leavers online. She creates online havoc through her aggressive online comments and attacks people based on their online posts, which is quite an unusual behaviour for someone of her age and status. Nevertheless, when the news item "LOCAL MAN ARRESTED FOR ASSAULT," referring to one of the names attacked by Carol, pops up on her computer, she panics and disconnects all her electronic devices. In the monologue, she involves herself in online attacks for the sake of its excitement without being fully aware of the tension that the referendum has caused among the citizens. 
Welsh playwright and screenwriter Abi Morgan prefers an indirect approach to Brexit in her monologue "The End." Helen, the main protagonist, is in her mid-60s and struggles to cope with her new status after her husband has left her after 43 years of marriage. However, beneath this crisis, Morgan hints that Helen's failing marriage is a metaphor for Brexit, husband and wife symbolising the UK and the EU. While 43 years of marriage corresponds to the time the UK has been a member of the EU, which was then named the European Economic Community, Helen represents the EU while her husband stands for the UK that decides to leave the union, as can be understood from their arguments. In her piece, Morgan draws a subtle comparison between a complicated political decision and a failing marriage. This simplification, in one way, enables the audience to comprehend the discussion in clear terms. In addition, Morgan's monologue can be counted just as an explanation of Brexit and its aftermath through the metaphor of marriage. This makes the monologue quite objective compared to the monologues discussed above. Morgan recaptures the referendum through the metaphor of marriage rather than focusing on the effects of the referendum and the reactions of the individuals.

In a similar vein, "Go Home," by Charlene James, approaches Brexit through the metaphor of relationships. In this 'short,' Reece, a young man in his $20 \mathrm{~s}$, shares his views about how the referendum has changed his relationship with his girlfriend. The tone of the monologue gets quite pessimistic when references are made to the ways in which the referendum divided the country. Reece narrates how he left a letter to Hannah, in which he asks her to give him a chance and come with him to his hometown to speak with his family and understand the reasons for their voting to leave. In other words, Reece proposes a way to establish a dialogue to sort out differences. In fact, the whole monologue unfolds as Reece is waiting for the arrival of the train by which he hopes Hannah will come to his town. The monologue ends on a note that renders optimism and hope: "He stands next to the station name sign. A train approaches. The train departs. Reece has his back to us. He walks along the platform holding Hannah's hand" ("Go Home"). Hence, James places emphasis not on the referendum or on the possible political outcomes of Brexit, but on 
the importance of dialogue and understanding among different groups. Thus, the monologue goes beyond politics and points out the necessity to establish a communication.

Overall, it can be argued that these nine playwrights represent a political issue from different angles. Different parts of the country, as well as different classes and age groups, get a chance to express their viewpoints through these monologues. The focus is mainly on the influence of the referendum on ordinary people rather than on defending the cause of the leavers or of the remainers. The characters are reflected, along with their vote in the referendum, in connection to others. As Kritzer suggests, "[i]n place of idealism, contemporary political drama offers a pragmatic humanism. Many of the plays locate the primary meaning of human life in the connection to others in family or community" (219). As the monologues prove, individuals matter beyond any other abstract discussions of Brexit since they "hold the potential for considerable power" (Kritzer 219). Moreover, the nine monologues aim to create a dialogue among different people in order to provide different stances on the issue. The monologues do not question personal decisions but seek to broaden understanding of opposing opinions and perspectives, as Billington expects from political theatre: "I also look to political theatre both to inform and heighten consciousness" ("P is for"). Contemplating this opinion, instead of idealising Brexit or approaching it as a political debate, problems, which are social and economic rather than political, are voiced. Overall, the Guardian project aims to rather evoke mutual understanding and tolerance than focus on a divided nation. This might be the main reason why Brexit Shorts can be considered as an example of political drama in the twenty-first century. Billington admits that "it was pointless to expect political theatre to topple governments or provoke legislation" ("P is for"). The monologues in the project are not meant to change the result of the referendum. However, they significantly influence the evolution of political theatre, since they give voice to ordinary citizens to express their ideas, concerns and feelings in order to restore their connection with each other. 


\section{The Shift from Stage to Online Platform}

In the Guardian's project, each playwright approaches Brexit from the perspective of a different region in the UK and of characters from different backgrounds in order to explore the complex nature of Brexit. Nevertheless, in contrast to the traditional form of theatre, the monologues in the project have been produced in real-life locations and posted on the Guardian's website. Although the playwrights' approach towards Brexit in these monologues exemplifies the changing definition of political theatre, the form of the monologues poses a challenge. These monologues were not intended to be staged but to be aired online. Thus, to which extent can these short videos stand for political theatre? Arguably, it should be noted that there has always been an experimental side to political theatre. As can be traced back to 1920s and 1930s, the main aim of political theatre has been to reach and organise more people. Agitprop, living newspaper, and bread and puppet have played a significant role in creating the basis of political theatre due to their mode of performance and structure. The term agitprop refers to political propaganda acted for the masses in union halls, at factory strikes, practically at any venues where they can reach working-class people, staged with stereotypical characters and minimal stage props reflecting day-to-day political issues. Similarly, the living newspaper aimed at creating a theatrical counterpart of the newspaper performed anywhere outside with audience. In the bread and puppet theatre, street performances raised their voices against authority relying on huge puppets, masks and body movements rather than dialogue. Nevertheless, what is common in the performances that lie at the root of political theatre is the freedom to perform in any place where they can gather an audience. In the digital age experienced in the twenty-first century, there is hardly any other better medium to reach a wider audience than the Internet. Thus, it is necessary to examine how online monologues are digitally adapted to represent political theatre at a new level. This does not necessarily entail the death of theatre. Inevitably, the Internet has become one of the fastest ways to convey an idea or an event to people worldwide. In this regard, Brexit Shorts deliver a significant message on Brexit to people all around the world, who would otherwise not have the 
chance to see them on stage. These monologues open up the possibility of considering the Internet as a new platform for dramatic performance, beyond the conventions of classical understanding of theatre.

With technological developments, and more specifically, the Internet, affecting various aspects of life, art forms have also been adapted accordingly. In this regard, theatre and the digital have provided a fruitful area of research for scholars to evaluate the contribution of technology and the relation between them. Apart from the inclusion of technology in the dramatic performance, which has created the term cyber-theatre, streaming and broadcasting of performances at a movie theatre or on personal computers are examples of the digitalisation of theatre. The National Theatre, for instance, has initiated National Theatre Live to broadcast the chosen plays to wider audiences in various countries in the 2009-2010 season. Their annual report mentions the success of the project as follows: "Research conducted by NESTA on the broadcasts of Phèdre and All's Well That Ends Well showed that NT Live performances attracted a significant number of first-time theatre-goers and that there were no cannibalisation effects on the NT box office but, on the contrary, NT Live encourages audiences to attend theatre more frequently." Although further and more detailed research is required to look into the influence of streaming and broadcasting theatre performances, the easy accessibility of digital works is unquestionable. The online videos are also a more popular medium with digital natives, a term referring to young generations born into the digitalised world and popularised by Marc Prensky. Hence, National Theatre's broadcasting practice and its success indicate the importance of the online platform of Brexit Shorts.

Additionally, Brexit Shorts are influenced by verbatim theatre. The testimonies and documents used in verbatim theatre have been replaced with monologues in Brexit Shorts, and each of these monologues can be considered a testimony at the same time. Rather than incorporating reallife characters' testimonies to the stage, as in the case of The Colour of Justice, in which the play's plot consists of testimonies of real-life characters, a fictional character's monologue is represented as a testimony. In other words, it can be said that the playwrights reverse the method of verbatim theatre. The recorded speeches that are re-created on 
the stage in verbatim theatre are replaced with fictional characters' recorded speeches. Harry Derbyshire and Loveday Hodson quote Richard Norton-Taylor: "There is something extraordinary about real people saying real things about extraordinarily important events" (199). The playwrights of Brexit Shorts create their own characters to reveal real things about Brexit. Hence, although fictionalised, Brexit Shorts offer a virtual reality through this technique at the same time. All the monologues have been filmed in real locations rather than on stage. The audience meet with these characters during their daily activities. To give a few examples, Dalir is shown in his office, Helen is spending her evening at home whereas Reece is spotted at the station while waiting for his girlfriend. Thus, the short videos give the illusion that the audience is watching the testimonies of rather real than fictional characters. The videos convey a sense of reality as if watching the interviews of random citizens around the UK. Both the accents of the characters and the setting contribute to this feeling. In this regard, it can be argued that these monologues challenge the perceptions of the audience. This sense of reality created in these videos through reversed testimonials, encourages a virtual dialogue with the audience. The real locations used in the monologues create a sense of reality. The sense of watching a play, with these online monologues shot in real locations, is replaced with a virtual reality. Yet, whether this constructed reality enables the audience to connect more closely with the stories narrated in the shorts compared to live theatre is a question that requires further research on the audience as well. Overall, the Guardian's project proposes a new and more accessible medium, and the technique of a reserved verbatim theatre to voice a political issue of the time. Hence, Brexit Shorts technically offer a rather bold alternative for the ever-changing political theatre than only a mere reflection of a major political development.

\section{A New Era? Monologues as Performance}

Apart from contributing to the changing definition of political theatre and the crucial role of the digital platform in its mediation, the Guardian's project also highlights the growing significance of monologue as a 
theatrical form. Following in the footsteps of the Guardian's monologues, the Royal Court has announced a new project to commemorate the Windrush generation. As stated in the press release by the Royal Court, " $[t]$ o mark seventy years after the arrival of passenger liner V Empire Windrush at Tilbury Docks, Essex, and in response to the recent Windrush scandal, writer/director Lynette Linton has commissioned and is curating Passages: A Windrush Celebration, a series of seven monologue films presented by the Royal Court Theatre." For another political issue, race relations in the UK, the Royal Court has opted for the same medium and form as the Guardian has chosen for Brexit. Similarly, BBC Radio Manchester has announced an open call for monologues to be performed at the Royal Exchange Theatre in order to mark the anniversary of one hundred years since the women won the right to vote. Such developments can be considered a hint to how monologues may represent a form to raise awareness of political issues. Thus, along with the changing definition of political theatre, these new developments indicate a possible chance for this medium. Moreover, the choice of monologue to commemorate another socio-political event, which will be screened rather than performed, indicates the significance of the Guardian's project for the medium it has initiated.

\section{Conclusions}

Political and social development require a revised definition of political theatre as can be observed in the time frame from the 1920s to the 2000s and later in the new millennium. From workers' movement to the Brechtian elements of leftists' playwrights, from in-yer-face to immigrant playwrights and to verbatim theatre, political theatre is in a constant flux. In relation to this aspect, the political event of the twenty-first century, Brexit, has created a new opportunity for playwrights to contribute to the understanding of political theatre. As Billington suggests, "different writers are using different methods and, while we used to think political theatre meant public plays on public issues, there are many different approaches to it at the moment" ("The State" 95). The Guardian has initiated an undoubtedly compelling project giving nine outstanding 
playwrights the opportunity to share their perception of Brexit through short monologues that give wider responses to the referendum. Nevertheless, instead of reflecting a particular stance regarding the referendum, all these monologues raise awareness of the necessity to understand and accept differences. It can be argued that these monologues open up a dialogue related to different opinions on Brexit. As the state of a divided nation has begun to be discussed in the wake of the results of the referendum, the nine playwrights emphasise the significance of dialogue via the Guardian's partnership with the Headlong theatre company. In "How Brexit Ruins my Life," Aleks Sierz expresses his discomfort about Brexit. With regard to post-Brexit theatre, Sierz explains that "Brexit has also spoilt my theatre-going. It has forced me to watch Rufus Norris's execrable My Country; A Work in Progress (National, 2017). Unforgivable. Brexit has means that any new play is suddenly all about only one thing" ("How Brexit"). The Guardian's project might add to Sierz's discomfort. Brexit Shorts also contribute to the change in terms of the digitalisation of performance and changing form of political theatre. Thus, more important than the subject matter and the message, Brexit Shorts initiate the beginning of a new era with a new form and means of mediation in the continuous development of political theatre. As significant as the subject matter of the Guardian's Brexit Shorts may be, the use of the digital platform and the form of monologue attach high value to the project.

\section{Works Cited}

Beck, Sarah. "Appropriating Narratives of Conflict in Contemporary Verbatim Theatre: A Practice-as-Research-led Investigation into the Role of the Playwright." PhD Diss. University of London, 2016.

Billington, Michael. "P is for Political Theatre." The Guardian 27 Mar.2012. Web. 03 July 2017.

---. "My Country: A Work in Progress Review - Carol Ann Duffy Tackles Brexit." The Guardian 13 Mar. 2017. Web. 1 July 2017.

---. "The State of Reviewing Today." Theatre in Crisis: Performance Manifestos for a New Century. Ed. Maria M. Delgado and Caridad Svich. Manchester: Manchester UP, 2002. 54-57. 
Clapp, Susannah. "My Country: A Work in Progress Review - A Laudable but Limp Look at Brexit Britain." The Guardian 19 Mar. 2017. Web.10 May 2019.

Derbyshire, Harry, and Loveday Hodson. "Performing Injustice: Human Rights and Verbatim Theatre." Law and Humanities 2 (2008): 191-211.

Edgar, David. "Doc and Dram.” The Guardian 17 Sept.2008. Web. 30 June 2017.

Gale, Maggie B., and John F. Deeney. "Early Political Theatres: Introduction." The Routledge Drama Anthology and Sourcebook: From Modernism to Contemporary Performance. Ed. Maggie B. Gale and John F. Deeney. London: Routledge, 2010. 290-309.

Graham, James. "Burn.” The Guardian 26 June 2017. Web. 28 June 2017.

Gregg, Stacey. "Your Ma's a Hard Brexit." The Guardian 19 June 2017. Web. 25 June 2017.

Hare, David. "Time to Leave.” The Guardian 19 June 2017. Web. 25 June 2017.

Holderness, Graham. "Introduction." The Politics of Theatre and Drama. Ed. Graham Holderness. New York, NY: St. Martin's P, 1992. 1-17.

James, Charlene. "Go Home.” The Guardian 19 June 2017. Web. 25 June 2017.

Kennedy, A. L. "Permanent Sunshine." The Guardian 19 June 2017. Web. 25 June 2017.

Kritzer, Amelia Howe. Political Theatre in Post-Thatcher Britain: New Writing 1995-2005. London: Palgrave, 2008.

Luckhurst, Mary. "Verbatim Theatre, Media Relations and Ethics." A Concise Companion to Contemporary British and Irish Drama. Ed. Nadine Holdsworth and Mary Luckhurst. Oxford: Blackwell, 2008. 200-222.

Morgan, Abi. "The End." The Guardian 26 June 2017. Web. 28 June 2017.

National Theatre. "My Country; A Work in Progress." National Theatre. Web. 28 June 2017.

O'Hanlon, Dom. "Review of My Country: A Work in Progress by Carol Ann Duffy at the National Theatre." London Theatre 13 Mar. 2017. Web. 10 May 2019.

Owen, Gary. “The Pines.” The Guardian 26 June 2017. Web. 28 June 2017.

Patterson, Michael. Strategies of Political Theatre: Post-War British Playwrights. Cambridge: Cambridge UP, 2003.

Peake, Maxine. "Shattered." The Guardian 26 June 2017. Web. 28 June 2017.

Sierz, Aleks. "How Brexit Ruins my Life." Writings. 1 July 2018. Web. 2 July 2018.

Syal, Meera. “Just a T-shirt.” The Guardian 19 June 2017. Web. 25 June 2017.

Taylor, Paul. "My Country: A Work in Progress." Independent 13 Mar.2017. Web. 29 June 2017.

The Royal Court. Press Release. 22 June 2018. Web. 27 July 2018.

The Royal National Theatre. The Royal National Theatre Annual Report and Financial Statements 2009-10. London: The Royal National Theatre, 2010.

Upton, David. "My Country; A Work in Progress." British Theatre Guide 18-22 Apr. 2017. Web. 10 May 2019.

Wiegand, Chris. "Brexit Shorts: Giving Voice to a Divided Britain through New Dramas." The Guardian 23 June 2017. Web. 25 June 2017. 